$\beta$ blockers who require a calcium antagonist for the treatment of angina are prescribed one that has no effect on cardiac conducting tissue.

We thank Mrs Sheila Haugh for typing this manuscript.

1 Van Buskirk EM, Fraunfelder FT. Timolol and glaucoma. Arch Ophthalmol 1981;99:696.

Findlay IN, Gillen G, Elliot AT, Dargie HJ. The treatment of angina pectoris with calcium channel and beta-blockers, efficacy and effect on cardiac function. [Abstract.] $f$ Am Coll Cardiol 1984;3:482.

3 Hutchison SJ, Lorimer AR, Lakhdar A, McAlpine SG. $\beta$ Blockers and verapamil: a cautionary tale. BrMed J 1984;289:659-60.

4 Johnston DL, Lesoway R, Humen DP, Kostor WJ. Clinical and haemodynamic evaluation of propranolol in combination with verapamil, nifedipine and diltiazem in exertional angina pectoris: a placebo-controlled, double-blind, randomised crossover study. Am $\mathcal{f}$ Cardiol 1985;55:680-7.

5 Hitchings RA. Beta-blockers in the treatment of chronic simple glaucoma. $\mathrm{Br}$ Med $\mathcal{F}$ 1982;285: 84-5.

(Accepted 30 Seprember 1986)

University Department of Medical Cardiology, Royal Infirmary, Glasgow G31 2ER

S D PRINGLE, MRCP, registrar

Department of Ophthalmology, Gartnavel General Hospital, Glasgow G11

CAROLINE J MACEWEN, FRCS, registrar

Correspondence to: Dr Pringle.

\section{Sweat osmolality in Down's syndrome and cystic fibrosis in an Indian population}

Several reports have indicated that sweat electrolyte concentration or osmolality is increased in patients with cystic fibrosis, ${ }^{1-3}$ whereas little is known about other clinical conditions in which sweat osmolality is altered. There is also a gap in our knowledge about physiological and pathological factors that could affect the sweat osmolality value. Furthermore, no studies of sweat osmolality in an Indian population have to our knowledge been reported. We therefore measured sweat osmolality in various clinical conditions in an Indian population.

\section{Patients, methods, and results}

Apparently healthy subjects of different ages and sex were invited to be control subjects. Patients were selected from those attending the National Institute of Mental Health and Neuro Sciences mental retardation clinic and from those referred from other centres. Sweat induction and collection was carried out with Webster's sweat collection system, which comprised iontophoretic equipment and a macroduct system, using the procedure described by the manufacturer. Osmolality of the sweat specimens was measured in a vapour pressure osmometer (Wescor, model 5100), which was precalibrated against reference standards ranging from $100 \mathrm{mmol}$ (mosmol) $/ \mathrm{kg}$ to $1000 \mathrm{mmol} / \mathrm{kg}$. Each sample was assayed in triplicate, and the average reading was taken as the final value. The results were analysed by Student's $t$ test.

The normal range of sweat osmolality was established in an Indian subpopulation $(n=830)$ of apparently normal subjects with an age range of 1 to 60 years. Most responded to pilocarpine iontophoresis by sweating (25-100/ $\mu \mathrm{l}$ per single stimulation). On rare occasions, however, some subjects did not respond even to repeated pilocarpine iontophoresis. Sweat osmolality in the normal group as a whole, irrespective of age and sex, ranged from 100 to $150 \mathrm{mmo} / \mathrm{kg}$. When this group was divided on the basis of age and sex a significant difference $(p<0.001)$ in sweat osmolality was observed between men (113.7 (SD 9.5) $\mathrm{mmol} / \mathrm{kg} ; \mathrm{n}=60$ ) and women $(149 \cdot 8(10 \cdot 1) \mathrm{mmol} / \mathrm{kg} ; \mathrm{n}=100)$ aged 11 to 15 years. In the next age group (16 to 35 years) sweat osmolality remained about the same in both sexes. In $\operatorname{men}(105 \cdot 7(8 \cdot 6) \mathrm{mmol} / \mathrm{kg} ; \mathrm{n}=180)$ and women $(140 \cdot 22(20 \cdot 0) \mathrm{mmol} / \mathrm{kg} ; \mathrm{n}=160)$ aged over 35 , however, the sweat osmolality pattern was similar to that in the group aged 11 to 15 .

The figure shows that the highest sweat osmolality in normal subjects, irrespective of sex and age, did not exceed $160 \mathrm{mmol} / \mathrm{kg}$. On the other hand, sweat osmolality in patients with Down's syndrome $(228 \cdot 41(40 \cdot 0) \mathrm{mmo} / \mathrm{kg} ; \mathrm{n}=20)$ and clinically confirmed cystic fibrosis $(240.41(57 \cdot 0) \mathrm{mmol} / \mathrm{kg} ; \mathrm{n}=6)$ was always higher than $160 \mathrm{mmol} / \mathrm{kg}$. Such patients also responded poorly to sweat induction by pilocarpine iontophoresis.

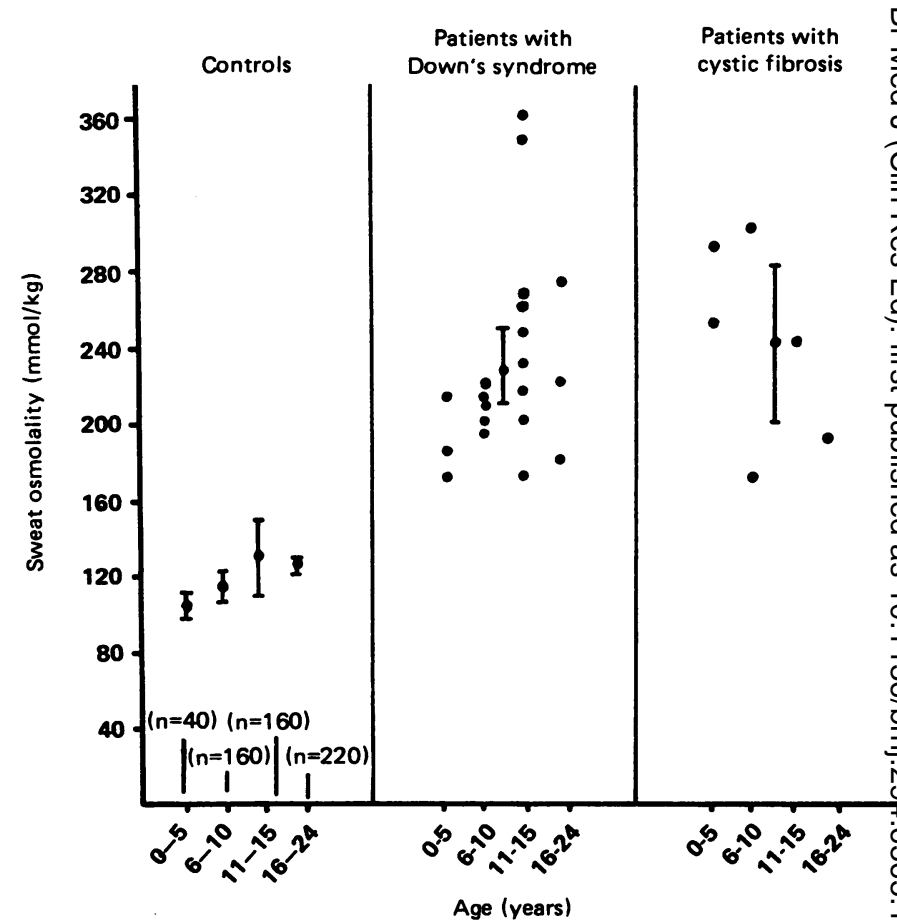

Sweat osmolality in control subjects matched for age and patients with Down's syndrome and cystic fibrosis. Bars represent SD. Mean and SD are given for each age group in control subjects but for whole group in patients with Down's syndrome and cystic fibrosis.

\section{Comment}

An increased sweat electrolyte concentration is usually considered to be a discriminatory test for cystic fibrosis. ${ }^{1-4}$ Recent trends in sweat analysis have shown that sweat osmolality can be used as an alternative to the estimation of electrolyte concentration, ${ }^{5}$ and an increased sweat osmolality is considered to be a confirmatory test for clinically suspected cases of cystic fibrosis. In the present study we noticed that sweat osmolality fluctuates during a person's life span, the changes being associated with the onset of puberty and menopause, implying that hormone state plays a part in sweat physiology. In patients with cystic fibrosis and Down's syndrome response to pilocarpine stimulation in terms of amount of sweat was poor, and the proportion of nonresponders to pilocarpine was significantly higher in these patients $(>10 \%)$ than in the normal population (3\%)

We have thus established a normal range of sweat osmolality in an Indian subpopulation and have highlighted the effect of factors such as age and sex on this characteristic. Furthermore, we have observed a difference in response to pilocarpine stimulation in the patient population ranging from good response (30-100 $\mu \mathrm{l} /$ single stimulation) through poor response (15-30 $\mu$ l sweat after repeated stimulation) to no response. In addition, we observed a consistent increase in sweat osmolality in patients with Down's syndrome and clinically suspected cystic fibrosis.

1 Gibson LE, Cooke RE. A test for concentration of electrolytes in sweat in cystic fibrosis of the pancreas utilizing pilocarpine by iontophoresis. Pediatrics 1959;23:545-9.

2 di Sant' Agnese PA, Darling RC, Perera GA, et al. Abnormal electrolyte composition of sweat in cystic fibrosis of the pancreas: clinical significance and relationship to the disease. Pediarrics cystic f16rosis of th:

3 Webster HL Barlow WK. New approach to cystic fibrosis diagnosis by use of an improved sweat inder

induction/colloction system and

5 Davis PB, Rio SD, Muntz JA, Dieckman L. Sweat chloride concentration in adults with pulmonary diseases. Am Reo Respir Dis 1983;128:34-7.

(Accepted 9 September 1986)

Department of Neurochemistry, National Institute of Mental Health and Neuro Sciences, Bangalore-560029, India

H GEETHA, MSC, lecturer on deputation K TARANTH SHETTY, PHD, associate professor

Correspondence to: Dr Shetty. 